\title{
Category Shifts In the English Translation of Harry Potter and the Philosopher's Stone Movie Subtitle into Indonesia (An Applied Linguistics Study)
}

\author{
${ }^{1}$ Herman, M.Pd \\ (Universitas HKBP Nommensen, Medan-Pematangsiantar, Indonesia)
}

\begin{abstract}
This research is conducted in order to find out the shifts in movie subtitle of Harry Potter especially for the Harry Potter and the Philosopher's stone Movie Subtitle into Indonesia. In translating text, shifts are inevitable. According to Catford (1965: 80) in Hatim (2001:15) classified the translation shifts into two major types of shift are identified: 'Level Shift' and 'Category shift. Category shift can be as structure, class, unit, and intra-system shift. Problems discussed in this research: 1) what kinds of category shifts found in the movie of Harry Potter and the Philosopher's stone into Indonesia subtitle? 2) what is the dominant category shift found in the movie of Harry Potter and the Philosopher's stone into Indonesia subtitle? The data of this research were taken from the movie subtitle of Harry Potter from English into Indonesia by Togap. Finally, the findings show: 1) all kinds of category shifts found in the subtitle from English into Indonesia, 2) the dominant category shift found in movie subtitle is unit shift.
\end{abstract}

Keywords: Shift, unit, structure, class, intra-system, movie, subtitle (titling)

\section{Introduction}

Nowadays, especially in globalization era, communication in many languages is very important. And of course, the method of communication is needed to apply the communication. But because of there are so many languages in all over the world, the communication become problem for them. The only solution of the problem in different language is through translation. "Translation is basically changing a text from SL into TL" Larson (1984:1). Catford (1965:20) defined translation as the replacement of textual material in the other language (TL). Moreover, Bell (1991:20) defines the phenomenon as "the replacement of a representation of a text in one language by a representation of an equivalent text in a second language." Baker (1998:77) defines equivalence as the relationship between a source text (ST) and a target text (TT) that has allowed the TT to be considered as a translation of the ST in the first place

Nida and Taber (1982:12) stated that translation consists in reproducing in the receptor language the closest natural equivalent of the source language message, first in terms of meaning and secondly in terms of style". Based to the definition, translating means transfer the message from SL into TL. The message in TL should have the equivalence and closely meaning with the SL. In conclusion, meaning is more important than style in translation.

Based on the importance of translation, the writer is interested in making a research in subtitles of movie. In fact, there are so many subtitles on screen almost everyday, everywhere; on television, film screen, and nowadays on DVD. Usually the viewers watch the programs and read subtitles without thinking or knowing how the translation has been done. Have you ever heard about "subtitle"? Subtitle is the key to understand the meaning of the contents in foreign languages.

In this paper, the writer will make a research of translation in Source Language (in English) into Target Language (in Bahasa Indonesia). When translating from the SL (in English) text into TL text (in Bahasa Indonesia), the translator must know the rules of both languages. Because both have different structure, so translation shift is needed. Catford (1965: 141), translation shift is "the departure from the formal correspondence in the process of going from the Source language into Target Language, two major types of "shifts" occur: level shifts and category shifts.

Technically, a translator has to know that in translating the source language to target one, shifts, equivalency and techniques are inevitable. In this occasion, the writer only focuses to the shifts in making the research for this paper. The object of this research is the translation which is found in the subtitle of Harry Potter and the Philosopher's stone movie from Source Language (English version) into Target Language (Indonesia version). Particularly, subtitle is created and used as a tool of communication and displayed as text and overlaid on the video in order to make the audience become easier to understand the movie. Therefore, the product (subtitle in TL) must be the good one so the audience will satisfy in using it. For that reason, the writer makes 
further analysis of translation through shifts in subtitling, it is hoped that this research will give contribution to the teachers and the students who study the translation

\subsection{Problems Of The Research}

Based on the above explanation, the problems created as the following:

1. What kinds of category shifts found in the movie of Harry Potter and the Philosopher's stone into Indonesia subtitle?

2. What is the dominant category shift found in the movie of Harry Potter and the Philosopher's stone into Indonesia subtitle?

\subsection{Objectives Of The Research}

The objectives of this research are to answer the problems as what have been mentioned in the previous point. They are:

1. To find out the kinds of category shifts found in the movie of Harry Potter and the Philosopher's stone into Indonesia subtitle

2. To find out the dominant category shift found in the movie of Harry Potter and the Philosopher's stone into Indonesia subtitle

\subsection{Scope of the Research}

There are two major types of translation shifts, namely: level and category. In this research, the writer will discuss only category shifts which cover unit, structure, class, and intra-system shift. In this case, the shifts in translation will be discussed through the text of movie. In movie, there will be subtitle that helps the audience in understanding it. There are so many movies, but in this occasion the writer will use the subtitle of Harry Potter movie, especially Harry Potter and the Philosopher's stone movie from English to Indonesia subtitle by the initial of translator named Togap.

\subsection{Significance Of The Research}

This analysis is very important for better understanding about the shifts in translation in the relation to the subtitle of movie. From this analysis, the writer hopes that this research will be useful for:

1. Making the readers know more about translation, especially the shifts;

2. Expanding the writer's knowledge about the shifts in translation which cover the unit, structure, class and intra-system shift;

In addition, the writer hopes that this analysis will be a worthy inspiration for those who want to do further research in the shifts of translation.

\subsection{Definition of Translation}

\section{Theoretical Review}

There are many theorists describe what translation is in different ways. They have their own explanation about translation. Translation is not only the transferring something written in source language into target language. Munday (2000:4) says that the term translation itself has several meanings: it can refer to the product and the process. The product involves the translated text and the process involves the translator changing an original written text (source language) into written text (target language) in different verbal language.

Translation is the replacement of textual material in one language (SL) by equivalent textual material in another language (TL) (Catford, in Machali 2000:5). it means that the translation is changing of the text material of the source language (SL) to the target language (TL) which in the target language the text has the equivalence in the source language.

Translation means rendering the meaning of a text into another language in the way that the author intended the text (Newmark, 1988). it means that the translation to translate the meaning of the text to another language must be intended with the message of the author.

Translation involves the rendering of a source language (SL) text into the target language (TL) so as to ensure that (1) the surface meaning of the two will be approximately similar and (2) the structures of the SL will be preserved as closely as possible but not so closely that the TL structures will be seriously distorted (Basnett, $1980: 2)$

Nida and Taber (1982:12) proposes a rather complete definition of translation. According to the two experts, "Translating consisting of reproducing in the receptor language the closest natural equivalence of source language message, first in terms of meaning and secondly in terms of style." The definition proposed by Nida and Taber contain some elements that should be taken into account by a translator in performing his/her 
task: reproducing the message, equivalence, natural equivalence, closest equivalence, priority on meaning and also style.

According to the definition, the translator should try to reproduce the message contained in the source language into the one in the target language. In this matter, what the translator should do in translating is to create the equivalent message, not the form in the target language. Or it can be stated that an emphases should be put on the reproduction of the message rather than the conversation of the form or grammatical structures. To get such equivalent message, many grammatical and lexical adjustments should be made.

Based on the various definitions above, it is known there are so many factors that should be considered to get a good translation. A good translation, therefore, does not sound like translation. It should be natural as if it is originally written in target language

\subsection{Concepts of Shifts}

Based on Oxford Advance Leaner's Dictionary (1985), "Shift is change position or place, substation of one thing to another". Catford (1965:141) gives the idea on shift, namely "The change of formal structure of the Source language into the Target language".

Catford (1965: 80) in Hatim (2001:15) classified the translation shift into two major types of shift are identified: 'Level Shift' and 'Category shift'. Level shifts means a SL item at one linguistic level has a TL translation equivalent at a different level. This shift commonly occurs with shift from grammar to lexis and vice versa. However, category shift means change from the formal correspondence in translation. Furthermore, it is divided into structure shift, class shift, unit shift, and intra shift.

1. Structure-shifts, which involve a grammatical change between the structure MH (modifier + Head) into HM (Head + Modifier)

2. Class-shifts, that grouping members of a given unit which is defined by operation in the structure of the unit next above. Class shift occur when the translation equivalent of a source language (SL) item is member of a different class form the original item.

3. Unit-shifts, which involve changes in rank, that is departures form formal correspondence in which the translation equivalent of unit at one rank in the source language (SL) is a unit at different rank in the target language (TL)

4. Intra-system shifts, which occur when 'SL and TL possess systems which approximately correspond formally as to their constitution, but when translation involves selection of a non-corresponding term in the TL system'. For instance, when the SL singular becomes a TL plural.

Details of category shifts will be introduced in the following parts

\subsubsection{Category Shifts}

Category shifts refer to unbounded and rank-bounded translation. The first being approximately normal or free translation in which source language and target language equivalents are up at whatever rank is appropriate. It is clear that category shift is unbounded, which might be normal of free translation, depends on what rank is appropriate. It includes, structure, class, unit, and intra-system shifts.

\subsubsection{Structure Shift}

The descriptive units of the grammar of any language are arranged into meaningful stretches or patterns. One single instance of these patterns is called 'structure.' This abstract category which applies to all units in the grammar of a language (except the one lowest in rank), accounts for the various ways in which one unit may be realized by the unit next below it. Sometimes, however, a unit may be realized by a unit above it. This phenomenon is known as rank shifting.

Languages exhibit a considerable amount of differences both in the realization of similar structures existing in these languages and in the type of structures existing in each language. It is worth mentioning here that the distinction between deep representation of linguistic relations and their surface realizations constitutes an important phase for the analysis of structural shifts.

A 'structure shift' involves a change in grammatical structure between ST and target text TT. Catford considers structure shifts the most frequent type of shifts that may occur at all ranks.

For example:

SL Text : Giant contract. (English)

TL Text: Kontrak Besar. (Indonesia)

It is clear here that there is a shift from M-H (modifier head) to H-M (head+ modifier) between the two versions above 


\subsubsection{Unit Shift}

A 'unit shift' where a strict rank-for-rank correspondence between SL and TL sentences, clauses, groups, words and morphemes is not observed: e.g. the English definite article translated by a change in word order in Russian; (Catford, (1965: 80) in Hatim (2001:15)

Unit shifts occur when translation equivalent of a source text unit at one rank in is a unit at a different rank in the target language. It includes shifts from morpheme to a word, word to phrase, clause to sentence, and vice versa. For example:
English
SL: impossible
Indonesian
TL: tidak mungkin

From example of translation above, unit shift can be found at Source Text (ST) is impossible (word), that is translated into Target Text (TT) tidak mungkin (phrase). It means that shift from word to phrase.

Unit shifts also can be from low level to higher level or from high level to lower level. It is caused by the differences of the amount of meaning component in different concept.

\section{A. Low Level to Higher Level}

$$
\begin{array}{ll}
\text { Example: } & \text { ST: Housekeeper } \\
& \text { TT: Pengurus rumah tangga }
\end{array}
$$

From the examples above, it is translation in term low level to higher level. It means that in the source language there is one word but after translated into target language became more than one word. It can be seen on word "Housekeeper" which is consists of one word was translated into "pengurus rumah tangga" which is consists of three words.

\section{B. High Level to Lower Level \\ Example: $\quad$ ST: Ultimate betrayal \\ TT: Pengkhianatan}

From the examples above, it is translation in term high level to lower level is the opponent of low level to higher level. In this case, the source language consists of more than one word and then translated becoming just one word. In the other hand, it can be said that the amount of word of source language is much more than in target language. The word "Ultimate betrayal" that consists of two words was translated into "pengkhianatan" that consists of just one word.

\subsubsection{Class Shift}

Class shift occurs when the translation equivalence of an SL item is a member of a different class from the original item. It is a change in word class. Catford defines class shifts following Halliday's definition "that grouping of members of a given unit which is defined by operation in the structure of the unit next above" (quoted in Hatim and Munday, 2004:45). Structure shifts entail class shifts. This is because of the "logical dependence of class on structure" (Catford, 1965:119).
Example:
ST: Annual report
TT: Laporan tahunan

From example of translation above, it can be seen at Source Text (ST), there is Annual (Adjective), that is translated into Target Text (TT) Tahunan (Noun). It means that there is class shifts from the sentences above and it is proved that structure shifts entail class shifts.

\subsubsection{Intra-System Shift}

A system is meant the closed number of elements among which a choice must be made. In fact, the terms available in each system in one language can show fundamental differences from the terms of the same system in another language. This can be considered as a major source of shifts at this level of language description. In other words, intra-system shifts refer to those changes that occur internally within a system. They are regarded only on the assumption that is formal correspondence between the two languages, i.e. ST-TT should possess approximate systems. The equivalence is said to occur at a non-corresponding term in the TL system. All languages have their systems of number, deixis, articles, etc. intra-system shifts happen when a term is singular in the source text and its textual equivalent is plural, or vice versa (a change in number even though the languages have the same number system).
Example:
ST: Victories
(English)
TT: Kemenangan
(Indonesia) 
From example of translation above, it can be seen at Source Text (ST), there is Victories (Plural), is translated into Target Text (TT) Kenenangan (Singular). The product (TT) should be in plural too but if it is transferred into "kemenangan- kemenangan", the meaning will sound weird. But it should be in singular (vice versa). The changes from plural to singular is called intra-system shift.

\subsection{Movie}

Movie is one of the parts in human's life. Based on http://en.wikipedia.org/wiki/Film, July $4^{\text {th }} 2012$; 20:27, A film, also called a movie or motion picture, is a series of still or moving images. The purpose of the movie is to entertain the audiences. The audience' satisfactions are different. For that reason, the producer, person who delivers a film project, made some different types of movie, known as genres. Based on http://simple.wikipedia.org/wiki/Movie, July $9^{\text {th }} 2012,11.03$ AM, genre is a word for a type of movie or a style of movie. Furthermore, genre can be divided into some parts:

a. Action movie refers to the gun fights, war, crimes, etc. This action movie also includes the stuntmen, person who replaces the main actor, in the script of the movie.

b. Animated movie is usually referring to the childish images in telling a story of the movie.

c. Comedies movie is a funny movie about people because of the silly things done in order to make the audience become laughing.

d. Documentaries movie is a movie which refers to the reality of events or about the real people.

e. Dramas movie is a film genre refers to the realistic characters dealing with emotional themes

f. Horror movie refers to excite the audience by a fear. The fears to the audience can be designed with music, lighting, and sets to add the fear feeling.

g. Thrillers movie is about a mystery or crime that are needed to be solved at the end of the movie. In this genre of movie, sometimes there are twists in it.

h. Fantasy movie is films with fantasy themes, including the magic, supernatural events. Fantasy movies also have an element of magic, myth, etc.

All kinds of movies above are not only made randomly based on the genre but they are also deeply involved in history and cultures. A film like Gone with the Wind is not only telling the action, war, but it also reflects the values and ideas of the culture that produced in it. Besides the history, all movies also reflect the culture and nation. Each cultures and nations have different values and will produces different sorts of films. The movie production will be rated by the system, movie rating system. This system is used to rate the movie before the people decide $t$ see a movie. There are some ratings for the movie, they are: a) General or G movies, are rated appropriate for all ages because they do not contain dirty language or adult materials, b) Parental Guidance Suggested or PG movies require parents to examine the movies then decide whether the movie is appropriate to be watched by their children or not, c) Parents Strongly Cautioned or PG-13 movies, contain violence and adult language. For those who are below 13 years old may not be allowed to watch this movie in the theater, d) Restricted or R movies contain some adult materials, and e) NC-17 for No One 17 and Under Admitted are for adults only. Children are not allowed to watch these movies. In sum, movies can give some benefits for audience if they are well selected to watch.

\subsection{Subtitle (Titling)}

Based on http://en.wikipedia.org/wiki/Subtitle, July $9^{\text {th }} ; 2012 ; 14: 29$ PM, subtitle (titling) is an explanatory or alternate title of a book, play, film, musical work, etc., in addition to its main title. Subtitle is made and translated by translators to audience in understanding the language spoken in the film. The subtitle is based on the interpretation of the on-screen dialogue displayed as text and overlaid on the video. There are so many kinds subtitles which written in many languages, such as Arabic, English, Indonesia, Malay, Vietnamese, Danish, etc. Subtitle is an art form and the style of the translated text can be in various ways. Some languages in the subtitle can be in formal and informal style. The style is depending to the translators and the need of the society. In the previous point mentioned that the movie is related to cultures and history. In sum, the subtitle (text) is also related to the cultures and history. Translators need to have a deep understanding in both languages, including the cultures and history. The quality of the subtitle or subtitling depends to the translators' ability

\section{Research Method}

This chapter discusses about the method and procedure that are used to solve the problem of the research. The writer has written some theories in the previous chapter. In order to describe research design, subject, object, technique of collecting data, and technique of analyzing the data. 


\subsection{Research Design}

Here for this research, the writer uses the combination of way of using descriptive qualitative and quantitative approach. The purposes of the usage of both are: a) Qualitative approach is used to describe the data. One of the characteristics of qualitative method is to see process we have to deal with setting, that is the place where all things to be researched. b) Quantitative approach is used to count the percentage of each variation that will be related to some non-linguistics factors.

\subsection{Data Source}

The data source was taken from the subtitles of Harry Potter and the Philosopher's stone movie. The writer analyzed the texts from subtitle and tried to find out the shifts in translation from Source Language (English) into Target Language (Indonesian) as the data to be analyzed.

\subsection{Technique Of Collecting Data}

There are many subtitles, especially the Target Language (Indonesia), but the writer chose one of them because the writer had analyzed and found that it was the best of all. The writer himself took the texts from subtitle and analyzed them based on the shifts.

\subsection{Technique Of Analyzing Data} following:

After getting the data from the research subjects, the writer uses some steps in analyzing the data as the

a. Analyzing the TL from movie subtitle of Harry Potter and the Philosopher's stone.

b. Finding the shifts used in the subtitle of Harry Potter and the Philosopher's stone movie.

c. Finding the dominant shifts from the movie subtitle in Harry Potter and the Philosopher's stone.

\subsection{Research Findings}

\section{Findings And Discussion}

\subsubsection{Category Shifts found in Harry Potter and the Philosopher's stone Movie Subtitle}

After analyzing the data, the researcher found in his research that all kinds of category shifts found in the subtitle of Harry Potter and the Philosopher's stone Movie. The category shifts used are: unit, structure, class, and intra-system shifts. For unit shift, it can be proven by (SL7,TL9) in data analysis below:

\section{(SL7,TL9)}

SL: 00:02:00,421 --> 00:02:05,333

Professor, I would trust Hagrid

with my life

TL: 00:02:18,750 --> 00:02:22,420

Professor.

Aku percaya pada Hagrid dengan nyawaku

For structure shift, it can be proven by (SL16,TL18) in data analysis below:

\section{(SL16,TL18)}

SL: 00:03:03,148 --> 00:03:08,059

He'll be famous. Every child

in our world will know his name

TL: 00:03:21,270 --> 00:03:26,670

Anak ini akan jadi terkenal.

Tak akan ada satupun di dunia kita yang tak mengenalnya

For class shift, it can be proven by (SL316,TL335) in data analysis below:

(SL316,TL336)

SL: 00:36:52,983 --> 00:36:58,605

Are you sure that's a real spell?

Well, it's not very good, is it?

TL: 00:39:10,530 --> 00:39:15,970

Kau yakin itu mantera sungguhan?

Tak terlalu bagus, bukan? 
For intra-system shift, it can be proven by (SL48,TL50) in data analysis below:

(SL48,TL50)

SL: 00:06:25,339 --> 00:06:29,123

...watching people press

their ugly faces in on you

TL: 00:06:43,480 --> 00:06:46,840

...melihat orang banyak

menempelkan wajah mereka yang jelek untuk melihatmu

\subsubsection{The dominant category shifts found in Harry Potter and the Philosopher's stone Movie Subtitle}

After analyzing the data above, the researcher found that the dominant category shifts used in the subtitle of Harry Potter and the Philosopher's stone movie subtitle is Unit Shift. It can be seen by the researcher in counting the shifts from the subtitle of Indonesia by Togap. The next dominant is structure shifts. As we know that, the most difference between Indonesia and English language is the position of Head-Modifier and Modifier-Head.

\subsubsection{Discussion}

The data discussed above only 50 percent of 100 percentage of the subtitle as sample to be shown as analysis. They are chosen as sample due to show that there are shifts used to any subtitle, especially in the movie of Harry Potter and the Philosopher's stone. After analyzing the data above, the researcher would like to discuss the subtitle from English into Indonesia. The discussions from the researcher is about the languages used in the subtitle in any subtitle are different. It means that the kind of language used is depending to the translator. Sometimes, the translator likes to use the non-formal language (especially Indonesia) or formal language. It can be seen through the comparison example below

\section{(SL7,TL9)}

SL: 00:02:00,421 --> 00:02:05,333

Professor, I would trust Hagrid

with my life

TL: 00:02:18,750 --> 00:02:22,420

Professor.

(SL38,TL40)

Aku percaya pada Hagrid dengan nyawaku

SL : 00:05:46,219 --> 00:05:48,045

I'm warning you now, boy.

TL : 00:06:04,530 --> 00:06:06,270

Kuingatkan kau, nak!

Look at the comparison above. The first data (SL7,TL9) and the second data (SL38, TL40). The words that have been bold above show the difference between the languages used by the translator. If related to the first data, it means that the second data of "warning you" should be transferred into "kuingatkanmu", but in fact, it is written "kuingatkan kau".

\section{Conclusion}

After describing an overview about the translation shifts and analyzing them in the movie subtitle of Harry Potter and the Philosopher's stone, some conclusions are drawn as the following:

1. Based on the movie, all category shifts are found in the subtitle from English into Indonesia, they are: unit, structure, class, and intra-system shift..

2. The dominant category shift found in subtitle movie is unit shift.

This paper has shown the analysis of the language of English to Indonesia context. More research needs to be conducted to make further analysis in other kinds of text in order to get a better understanding of shifts of translation because the writer feels that his research through movie subtitle is not enough yet to fulfill human's needs in further studying of translation shift.

\section{References}

[1]. Barnwell, Katherine G.L. 1984. Introduction to Semantics and Translation. England:Summer Institute of Linguistics

[2]. Bassnett, Susan. 1980. Translation Studies. Revised Edition. London and New York: Routledge

[3]. Bell, Roger.T. 1991. Translation and Translating: Theory and Practice. London and New York: Longman.

[4]. Catford, J.C. 1965. A Linguistic Theory of Translation. London: Oxford University Press 
Category Shifts in The English Translation of Harry Potter and The Philosopher's Stone Movie ...

[5]. Catford, J.C. in Harim, Basil. 2001. Teaching and Researching Translation. Beijing: Foreign Language and Research Press

[6]. Hatim, B. \& J. Munday 2004. Translation: An Advanced Resource Book, London/New York: Routledge

[7]. Machali, Rochayah. 2000. Pedoman Bagi Penerjemah.Jakarta: Grasindo

[8]. Newmark, P. 1988. A Textbook of Translation. New York: Prentice Hall

[9]. Nida, E dan C. Taber. 1982, The Theory and Practice of Translation. Leiden: Ej Brill.

[10]. Oxford Advanced Learners Dictionary. 1985. Oxford University Press.

[11]. Sanderson, John (ed.) 2005. Research on Translation for Subtitling in Spain and Italy. Murcia: Publicaciones de la Universidad de Alicante, pp 95. 